\title{
AT カット水晶振動子による小型荷重センサの設計と製作*
}

\author{
鳴海圭 亮*1, 朝 倉 歩*2, 林 育 菩*3 \\ 福田敏男*4, 新井史人*5
}

\section{Design and Fabrication of Compact Load Sensor Using AT-Cut Quartz Crystal Resonators}

\author{
Keisuke NARUMI, Ayumi ASAKURA, Yu-Ching LIN, \\ Toshio FUKUDA and Fumihito ARAI*6 \\ ${ }^{* 6}$ Department Bioengineering and Robotics, Tohoku University, \\ 6-6-01 Aramaki Aoba, Aoba-ku, Sendai-shi, Miyagi 980 8579 Japan
}

\begin{abstract}
The load sensor with A T-cut quartz crystal resonator has the characteristic that the resonant frequency changes by the external force, which achieves high sensitivity, high-speed response, and wide measurement range by a simple structure. Also it has the superior feature in the temperature and frequency stability. On the other hand, the quartz crystal resonator had been hardly applied to a force measurement because of low degree of mechanical characteristic, that is, it is weak to the impact, bend, and tension. The objective of this study is to construct the sensor mechanism that safely maintain the quart $z$ crystal resonator for the external force with flat structure. We designed and analyzed a novel retention mechanism of the quartz crystal resonator for the flat structure. The size of the retention mechanism is $6.0 \mathrm{~mm} \times 5.0 \mathrm{~mm} \times 4.4 \mathrm{~mm}$. The sensitivity of this sensor is 360 $\mathrm{Hz} / \mathrm{N}$. Output fluctuation of the sensor was less than $0.05 \mathrm{ppm}$ when the static pressure of $1.5 \mathrm{MPa}$ was applied. The proposed load sensor is small, sensitive and stable for static force measurement.
\end{abstract}

Key Words : Sensor, Piezo-Element, Micro-Mechanism, Structural Design, Nano \& Micro Machining

\section{1.}

現在，ロボット，医療および介護の分野で優れた荷 重センサが必要とされている. 測定対象としては, ベ ッド等に加わる荷重分布, 関節内の接触圧力の測定, 咬合力計測等が挙げられる. また，低侵襲医療技術に おいて，内視鏡やカテーテル挿入時の先端荷重やマニ ピュレータの操作力の測定等が必要である. 特に，ロ ボットが重い対象物から軽い対象物までを人間の手の 様に同様に操作する際, また, 初期荷重が印加した状 態での生体信号を計測する際には，高感度とともに広 計測範囲の荷重センサが必要になる.

従来の荷重センサには, ダイヤフラム型センサ, ひ ずみゲージ式センサ(1)および圧電振動形センサ年等が あるが, 高感度, 広計測範囲, 高速度応答, 小型およ び高耐久性等をすべて满たすセンサは存在しないのが 現状である. また，上記センサはアナログ出力である ために $\mathrm{AD}$ 変換器を要し，ノイズ対策などの複雑な信

* 原稿受付 2008 年 12 月 25 日.

*! 学生員, 東北大学大学院工学研究科(亚 980-8579 仙台书青 葉区荒巻字青葉 6-6-01).

*2（株）デンソー（昰 448-8661 刈谷市昭和町 1 1)。

*3 東北大学原子分子材料科学高等研究機構.

*4 正負, フェロー, 名古屋大学大学院マイクロ・ナノシステム

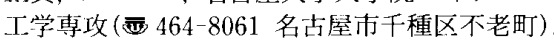

*5 正員, フエロー，東北大学大学院工学研究科.

E-mail : arai@imech.mech.tohoku.ac.jp
号処理が必要となる.

そこで, 本研究では圧電素子の一つである水晶に着 目した. 水晶は, 外部からの力に正確に比例した電荷 を発生し, 高感度であり広い計測範囲を有し, 温度安 定性や周波数安定性にも優れていることから，ガスセ ンササ(3)(4)，温度センサ(5)(6)，湿度センサ(7)(8)およびDNA センサ(9)などの各種センサに用いられてきた。.また同 様に, 荷重センサとしても研究挍よび開発されてきた. 水晶を用いた荷重センサとしてはキスラー社製の水晶 圧電式力センサ等がある. これらの荷重センサのセン シング原理は, 外部からの力により発生する電荷を検 出することである. しかしこの原理を利用した荷重セ ンサには，電気的なドリフトの影響を受けやすいとい う欠点がある.

反面, 水晶を振動させた状態で使用する水晶振動子 は, 外部からの力により共振周波数が変化するという 特性 ${ }^{(10)(11)}$ を持ち, 出力として電荷ではなく周波数を用 认ることで電気的なドリフトによる影響を受けにくく することが可能である. また，周波数出力を高速なデ ジタル信号として容易に処理できる. そこで本研究で はこの特性をセンシング原理として用いることとした. だが水晶振動子を荷重センサとして利用する際には, 水晶振動子の機械的な脆弱性に起因する技術的問題が 
存在する. 水晶振動子は衝擊, 曲げおよび引張りに弱 く, 荷重センサとして利用するには自身を安定に保持 する機構を必要とする.この脆弱性を考虑した研究 (12)(18)も過去に報告されているが, 荷重センサの小型化 という課題については充分に研究されていない. 水晶 に限定せず小型化に関する従来研究を考えると, 単結 晶シリコン微小はりの共振を用いるものもあるが, 高 分解能かつ広計測範囲を有しているとはいえない( ${ }^{(19) .}$

そこで本研究では, 水晶振動子を微細加工技術 により製作することでセンサ素子の小型化を実現 し，また，水晶振動子を外力に対して安定に保持 する機構を構築することにより, 水晶振動子を用 いた小型で安定な荷重センサを提案する. そして, 本センサの基礎動作特性を調査する.

\section{2. 水品振加子}

水晶振動子の断面模式図を図 1 に示す。本研究では 他の水晶より時間および温度安定性に優れた AT カッ ト水晶を用いた. AT カット水晶振動子は外部からの印 加電圧により, 表裏で電極の重なる部分で厚みすべり 振動を生じる. 外力を矢印の方向から印加することに より共振周波数が変化する.

\section{3. センサのシステム化}

3・1 㪣十上述したように, 水晶振動子は単独 では, 引張り, 曲げおよび衝撃に対して弱いため, こ れを安定に保持するべくセンサ保持機構の設計を行っ た. 試作した機構の概観図を図 2 に示す.

従来は水晶振動子を縦に保持して上部から圧縮力を

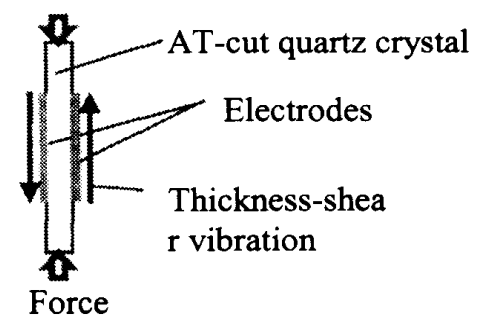

Fig.1 Cross Section of quartz crystal resonator

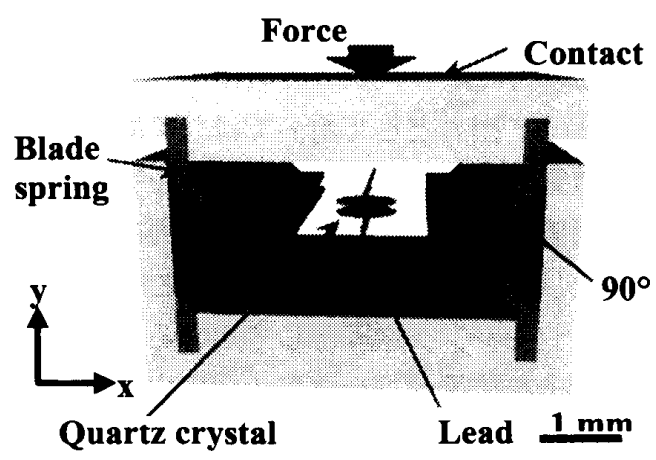

Fig.2 Schematic diagram of sensor retention mechanism.
付加する構造が一般的である(13,17-18)が，より安定させ るため水晶振動子をばねにより横向きに保持するよう 設計した. 本構造において，上部からの垂直圧縮力は 2 本の板ばるによって水平方向からの圧縮力に変換さ れる. 板ばねの構造を図 2 のような上下二重構造にす ることによって曲げモ一メントは相殺され，水晶振動 子に付与する曲げ応力を低隇することができると考え る. さらに，ばね構造により予期しない方向からの力 に対しても曲げ応力が発生しにくい構造となっている. 提案する保持機構の寸法は $6 \mathrm{~mm} \times 5 \mathrm{~mm} \times 4.4 \mathrm{~mm}$ であ る.

3・2 FEMによる応力解析 静力学的に考えると, 図 2 において水晶振動子には水平方向の圧縮力のみが 付与し, 曲げ応力は付与しないと考えられる. しかし， ばねの変形や材料特性を考慮して FEM による応力解 析を行った. FEM 解析ソフトとして COMSOL Multiphisics (v 3.4, COMSOL 社)を用いた. 解析項目は 水晶振動子に付与する荷重, 本センサの変形量および 本センサの許容応力である.

図 3 および図 4 は $1 \mathrm{MPa}$ の鈶直圧縮力をセンサの接 触面上部から印加したときの FEM 解析の結果である. 簡略のために板ばねと水晶振動子のみを解析対象とし, 外装は境界条件で代用させた。 また，図 3 は $\mathrm{x}$ 軸方向 のみの引つ張りおよび圧縮応力の分布を示し, 引張り 応力を正とする. 図 4 は $\mathrm{y}$ 軸方向の変位量の分布を示 す. 荷重負荷前の形状は点線で, 荷重負荷後の形状は 変位を 1,000 倍に強調して㬰線で示す. 比較のため, 図 4(a)に示すような, 鉛直方向からの圧縮応力を単純 に水平方向に変換する機構である板ばね(Type A) と $3 \cdot 1$ で設計した図 4(b)に示す上下 2 重構造の板ばね (Type B)の，異なる2つの構造の解析を行った.

図 3 より，水晶振動子には一様な $\mathrm{x}$ 軸方向の圧縮応 力が加わることが確認できた. 図 4(a)と(b)を比較する と, Type A では水晶振動子が曲げ応力を受けて場所に よって $0.015 \mu \mathrm{m}$ から $0.057 \mu \mathrm{m}$ のたわみが確認できる.

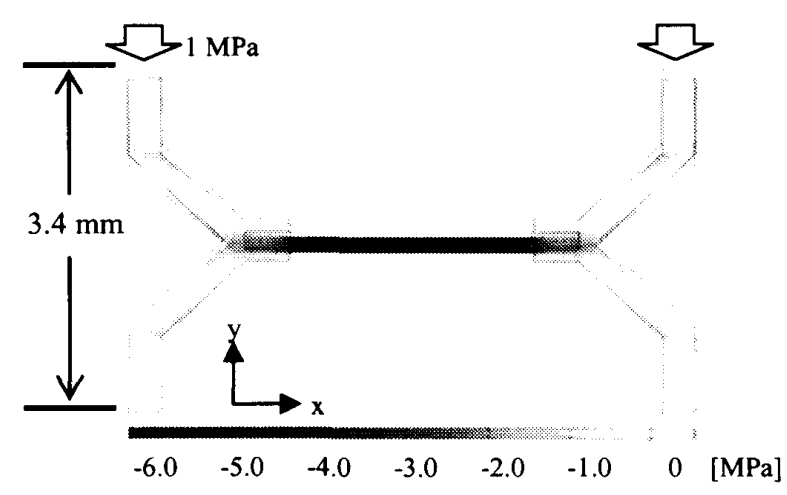

Fig.3 Stresses distribution in $\mathrm{x}$ axis. (Type B.) 
それに対し，Type B のような構造とすることで曲げ応 力が減少し，たわみが殁ど発生しないことが確認でき る. また, $1 \mathrm{MPa}$ の鈶直圧縮力においてセンサの変形 量は最大でもわずか $0.102 \mu \mathrm{m}$ であり, 本センサの高剛 性を確認できる.

次に，センサに本来予期しない方向から力を印加し たときの構造解析を行った. 図 5 は $\mathrm{x}$ 軸および $\mathrm{y}$ 軸方 向から $1 \mathrm{MPa}$ の圧縮応力を印加したときの, 水晶振動 子に付与する曲げ応力の分布図である. 図 5(a)は一般 的な水晶振動子の保持機構(Type C), 図 5(b), (c)は Type $\mathrm{B}$ において $\mathrm{x}$ 軸および $\mathrm{y}$ 軸方向から力を印加した場合 の解析結果を示す. 図 5(b), (c)より, 横方向からの荷 重を保持機構により吸収し，水晶振動子には曲げ応力 がほとんど付与されていないことが確認できる. 図 5(a)と(b)を比較すると, Type B の水晶振動子に付与す る曲げ応力は Type C と比べて最大で 1/150 であり, (a) と(c)との比較においても最大で $1 / 20$ である. よって, Type B の保持機構は高剛性であることが確認でき，予 期しない方向からの力に対してより安定であると考え られる。

最後に，本センサの許容応力および過負荷に対する 解析を行った. ばねの設計において, 静的荷重の場合 許容応力は引つ張り強さの $75 \%$ までとることができる. JS 規格によると, 今回板ばねの材料として用いたリン

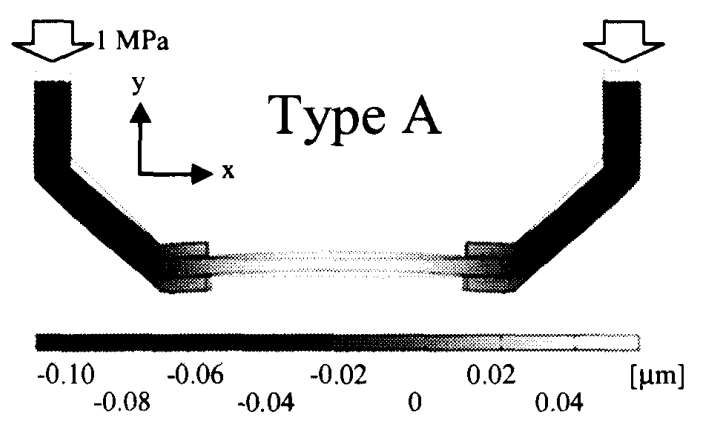

(a)

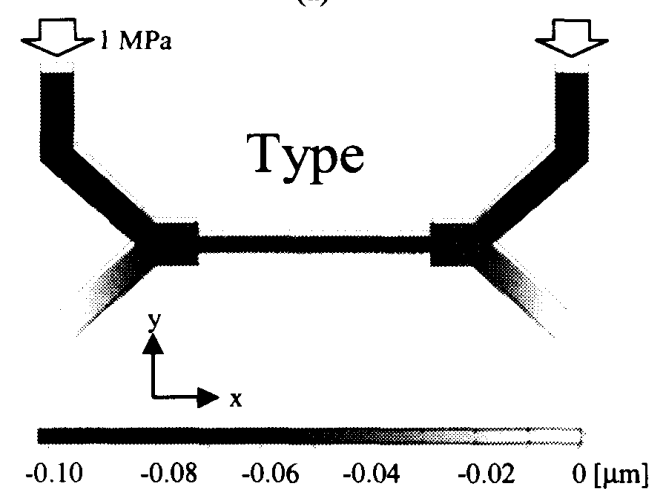

(b)

Fig.4 Displacement distribution in y axis. (a) Type A. (b) Type B.
青銅の引つ張り強さは厚みが $0.2 \mathrm{~mm}$ 以上のものにつ いて 470 $835 \mathrm{MPa}$ であり, リン青銅を用いたばねの許 容応力は $350 \mathrm{MPa}$ となる. 解析の結果, ばねの応力集 中を受ける部分の引張り応力が $350 \mathrm{MPa}$ に達するのは センサの接触面に $235 \mathrm{MPa}$ の圧力を印加したときであ ることがわかった. よって本センサの許容応力は約 $235 \mathrm{MPa}$ である. また, ばねの断面積が $1.8 \mathrm{~mm}^{2}$ であ るから, 本センサの鈆直方向の過負荷は $130 \mathrm{~N}$ である.

\section{4. 実解}

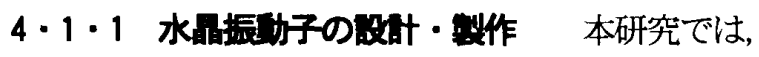
図 6 に示すような AT カット水晶振動子を設計した. 安定な振動を得る上では厚みすべり振動以外の振動を
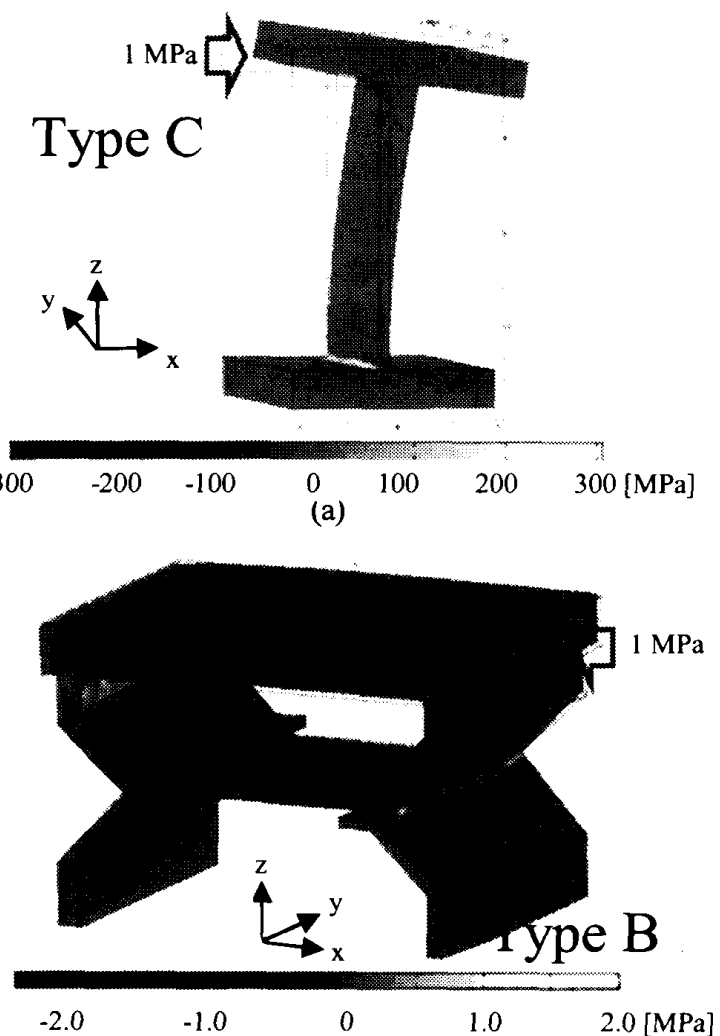

(b)

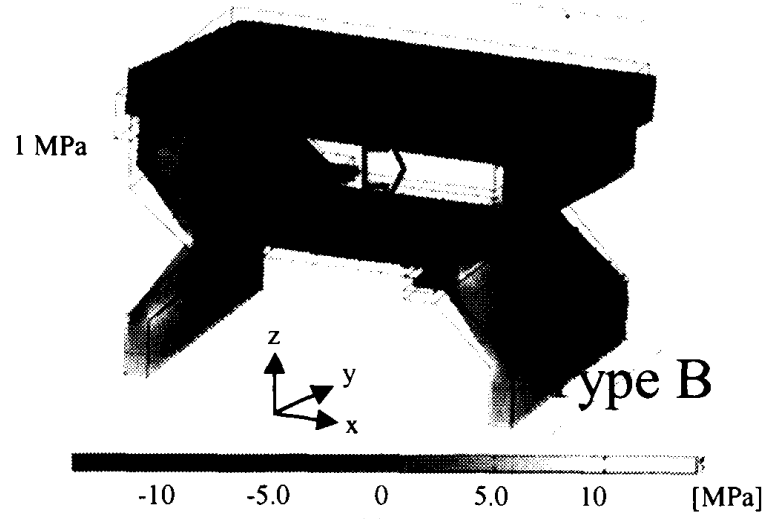

(c)

Fig.5 Bending stresses distribution. Type B 
生じることは好ましくないため, 電極形状を円形とす ることでこれらの振動の低減を図った. さらに, AT-cut 水晶振動子の X 軸の $34.8^{\circ}$ の方向から外力を加えるよ うに設計した. これは，村岡らによって応力感度が最 もよくなることが報告されている(20).

水晶振動子製作のプロセスを図 7 に示す。まず $\mathrm{AT}$ カット水晶表面にフォトリソグラフィにより図 6 に示 す電極パターンを複数転写し，Cr-Au をスパッタし， そしてレジストを剥離液によって除去することで水晶 上に複数の目的形状の電極を形成した. 上記の工程を 水晶の両面にわたって行い，個々の電極ごとにカット することで複数の水晶振動子を一度に製作した.ここ で，レジストの剥離を容易にするためにはレジスト壁 面を逆テーパー型にすることが求められる，そこで本 研究では，イメージ反転夕イプのフォトレジストであ る AZ-5214E (Clariant Corporation) を用いた. AZ-5214E は通常ポジ型のフォトレジストであるが，通常のマス ク露光に加え, 加熱および全面露光工程によりイメー ジを反転させることができる. その際, 図 7(e)に示す ような逆テーパー型の壁面が形成される.

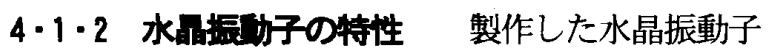
の周波数特性を, インピーダンスアナライザ(E4991A，

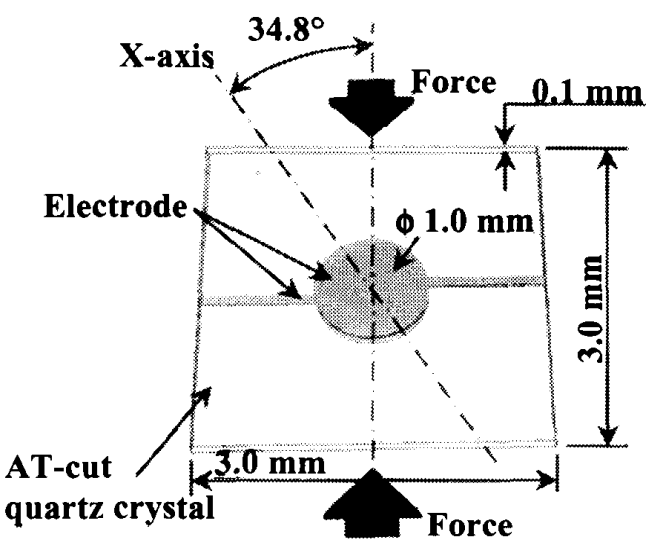

Fig.6 Schematic diagram of the quartz crystal resonator

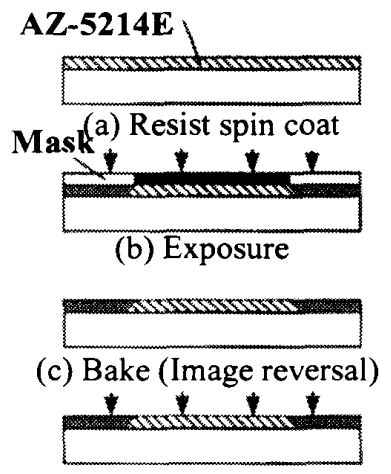

(d) Flood exposure

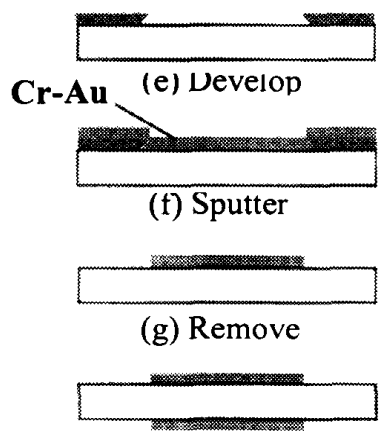

(h) Repeat (a) $\sim$ (g)
Fig.7 Fabrication process chart of quartz crystal resonator.
Agilent Technologies)によって計測した．図8は水晶振 動子のコンダクタンス特性とインピーダンス特性を示 す. 共振周波数付近で急激なインピーダンスおよびコ ンダクタンス変化が起こることが確認できる.また, 製作した水晶振動子 の $Q$ 值（Quality factor）(21) は約 16,000であった.

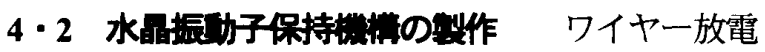
加工を用いてセンサ保持機構を製作した．板ばねの材 料には優れたば特性を有すリン青銅を用い，外装に は SUS304 を用いた．製作したセンサ保持機構の写真 を図 9 に示す．寸法は幅 $6.0 \times$ 奥行き $5.0 \times$ 高さ $4.4 \mathrm{~mm}$ である。

4.3 共振回路の议什・些作 水晶振動子は外部 からの電圧印加のショックにより振動を生じるが，そ の振動は長く続かない. また, 水晶振動子のインピー ダンス特性は共振周波数の奇数倍ごとに急激に変化し， これらの周波数で水晶振動子は発振する. ある特定の 周波数（ここでは共振周波数）の持続した発振を得る ためには，周波数を選択して増幅させるための回路が 必要である. 図 10 に水晶振動子のための基本的な共振 回路を示す．水晶振動子に負荷容量コンデンサを接続 して周波数選択回路を構築し, フィードバック抵抗と CMOS インバータからなる增幅器を接続することで,

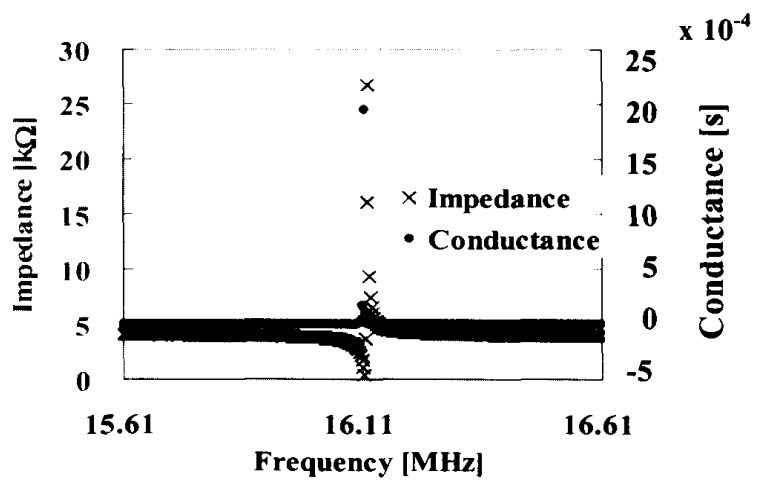

Fig.8 Impedance and conductance characteristics of quartz crystal resonator.

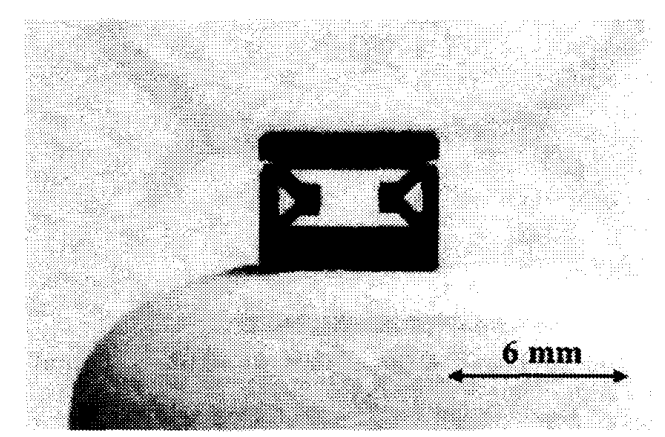

Fig.9 Photograph of sensor retention mechanism. (Without quartz crystal resonator) 
ある特定の周波数の持続した発振を得ることができる.

プリント基板加工機（DFM-400,MITS Electronics）を 用いてガラスエポキシ基板上に回路パターンを作成し， 抵抗およびコンデンサ等のチップを実装し共振回路を 製作した.ここで，回路定数は各水晶振動子にトライ アル・アンド・エラーにより設定する必要がある．表 1 にある水晶振動子における回路定数を示す. 基板寸 法は長さおよび幅 $12.0 \mathrm{~mm}$, 厚さ $1.6 \mathrm{~mm}$ である.

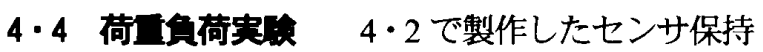
機構を用いて水晶振動子を保持し，水晶振動子の電極 と導線を導電性接着材で接着し，そして共振回路に配 線してセンサが完成した．荷重負荷実験システムを図 11 に示す. 共振回路に $4.5 \mathrm{~V}_{\mathrm{P}-\mathrm{P}}$ の電圧を直流電源 (PMC 500-0.1A, KIKUSUI ELECTRONICS Corporation) から印 加して水晶振動子を発振させ, 発振の確認をオシロス コープ（TDS 3014, Tektronix Ltd.）で行い, 出力を周波 数カウンタ (53131A, Agilent technologies) を用いて計 測した. ステージを上昇させ荷重センサを天井に押し 付けることにより荷重センサに荷重を印加し，ロード セル(9031A, KISTLER corporation)によって計測した. 図 11 の実験システムを用いて, 荷重を $45 \mathrm{~N}$ （接触面 積は $6.0 \times 5.0=30 \mathrm{~mm}^{2}$ であり, 圧力に換算すると 1.5 $\mathrm{MPa}$ ）まで印加したときの本センサの出力特性を図 12 に示す．同図より，荷重と共振周波数の間に単調増加 の関係が認められ，荷重センサとしての基礎動作特性 を確認できる. 同図において, 荷重負荷時の出力変化 を丸 $(\cdot)$ で, 除荷時の出力变化を十字 $(+)$ で示し

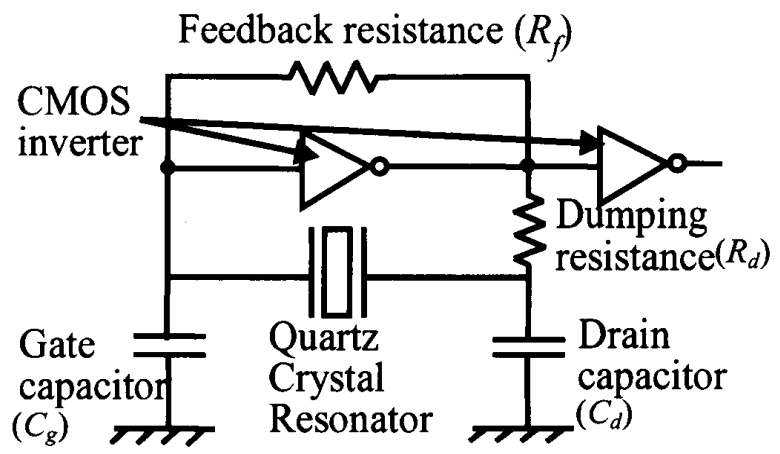

Fig.10 Basic oscillation circuit diagram for quartz crystal resonator in a measurement system.

Table 1 Parameters for oscillation circuit

\begin{tabular}{|c|c|c|c|c|}
\hline$f[\mathrm{MHz}]$ & $\mathrm{R}_{1}[\Omega]$ & $\mathrm{C}_{0}[\mathrm{pF}]$ & $\mathrm{C}_{1}[\mathrm{fF}]$ & $\mathrm{L}_{1}[\mathrm{mH}]$ \\
\hline 16.62 & 1223 & 2.18 & 1.48 & 6.19 \\
\hline
\end{tabular}

\begin{tabular}{|c|c|c|}
\hline $\mathrm{R}_{\mathrm{f}}[\mathrm{M} \Omega]$ & $\mathrm{R}_{\mathrm{d}}[\Omega]$ & $\mathrm{C}_{\mathrm{d}} \mathrm{C}_{\mathrm{g}}[\mathrm{pF}]$ \\
\hline 1 & 10 & 1 \\
\hline
\end{tabular}

$f$ : Resonant frequency, $\mathrm{R}_{1}, \mathrm{C}_{0}, \mathrm{C}_{1}, \mathrm{~L}_{\mathrm{l}}$ : Circuit constant of a quartz crystal
ている.ここから, 本センサのヒステリシスは $1.59 \%$, 非直線性は $2.49 \%$ と算出できる．また，センサの感度 は $360 \mathrm{~Hz} / \mathrm{N}$ である.

次に, 本センサ出力の時間安定性について考察する. 図 13(a)は電源 ON 直後の時間に対する出力安定性を, 図13(b)は $1.5 \mathrm{MPa}$ の圧縮応力印加時における出力安定 性を示す. 図 13(a)より, 本センサの出力は電源 $\mathrm{ON}$ 後 数分で安定化する. また図 13(b)より, 高負荷時にも出 力の変動は $0.05 \mathrm{ppm}$ 以下であることが示され, 本セン サにより静荷重が測定可能であることを実験的に確認 した.よって本センサは静荷重の計測が可能であり, 時間に対する安定性を備えていることが解る.ここで, 出力変動は荷重に換算して最大 $2.25 \mathrm{mN}$ である. よっ て本センサは従来研究 ${ }^{(18)}$ と比較して小型化であり, か つ感度および測定範囲に関して優れた性能を持つこと が確認できた。

また，本実験においては鈶直圧縮力のみによる計測 を行った. 鈶直方向以外からの力をセンサに与えた場 合の評価は今後の課題とする.

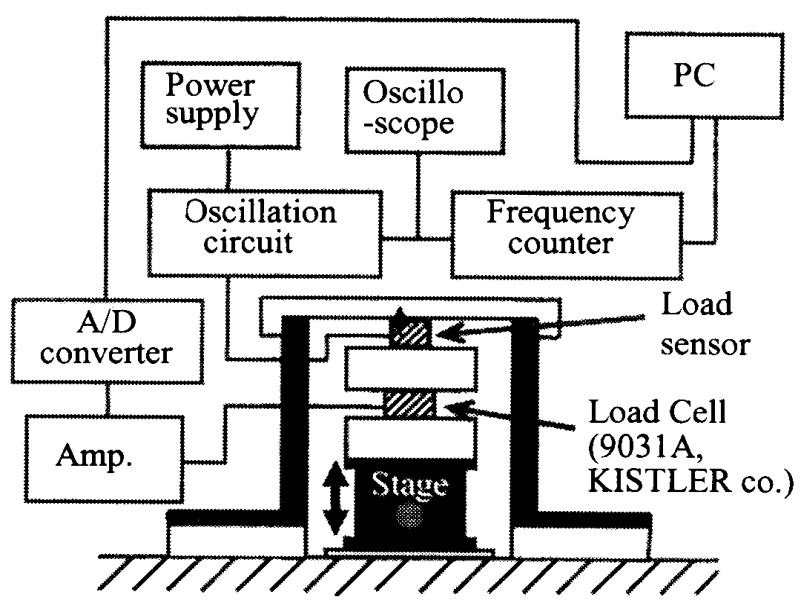

Fig.11 Experimental setup.

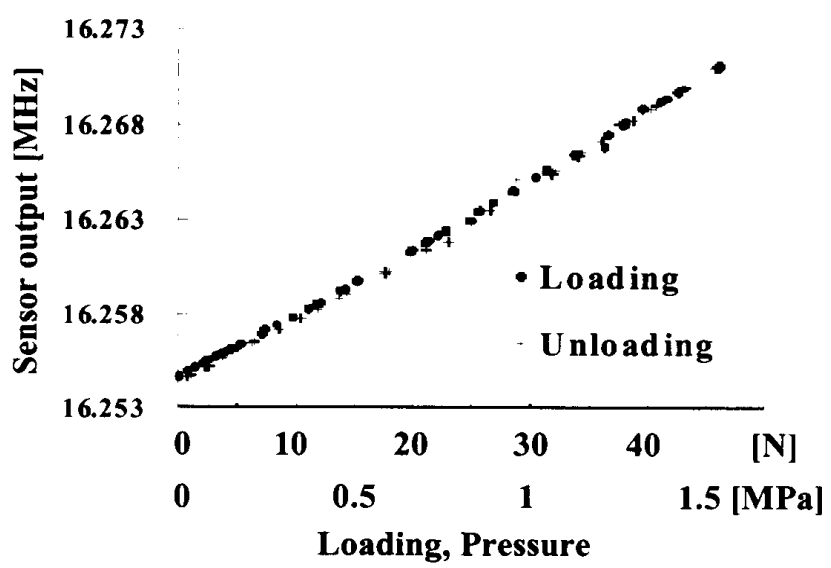

Fig.12 Performance of force sensor with quartz crystal resonator. (Temperature: $21.0^{\circ} \mathrm{C}$, Humidity: $38 \%$, Input: $4.5 \mathrm{~V}$ ) 


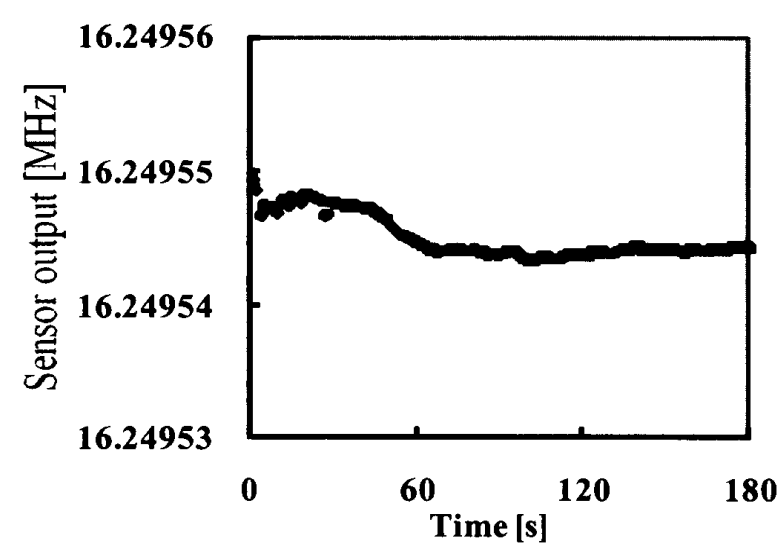

(a)

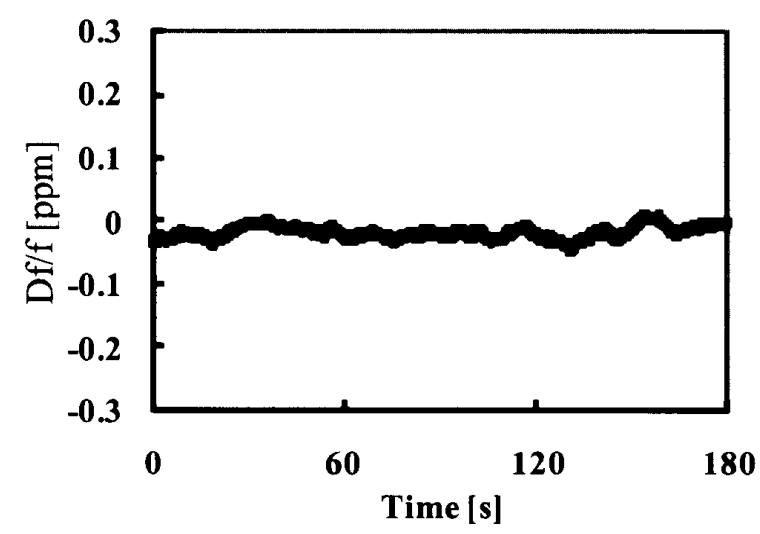

(b)

Fig.13 Static loading stability of sensor output. (a)Immediately after Power-On. (b)Under Impressed Pressure of $1.5 \mathrm{MPa}$

(Temperature: $21.0^{\circ} \mathrm{C}$, Humidity: $38 \%$, Input: $4.5 \mathrm{~V}$ )

\section{5. 结}

本研究では，微細加工技術により製作した水晶振動 子を用いた超小型荷重センサ機構を提案した. 提案手 法によれば, 従来より安定な構造の荷重センサを実現 できることを FEM による構造解析により確認した. 次 に，共振周波数と鈶直方向からの静荷重との間に単調 増加の関係が認められ，製作したセンサシステムが荷 重センサとして利用できることを実験的に確認した.

\section{暗 辞 \\ 本研究はマイクロ・メカトロニクスに関する共同研 究の助成および文部科学省の科研費 (18860005) の助 成を得た.}

\section{文}

(1) J. G. da Silva, A. A. de Carvalho, and D. D. da Silva, A Strain Gauge Tactile Sensor for Finger-Mounted Applications, IEEE Trans. Instrum. Meas., Vol. 51, No.1 (2002), pp. 18-22.
(2) URL:http://www.olympus.co.jp, Dec. 1999, (accessed 2007-3-16)

(3) M.T. S.R. Gomes, A.C. Duarte, J. A.B.P. Oliveira, Detection of $\mathrm{CO} 2$ using a quartz crystal microbalance, Sens. Actuators B, Vol. 26-27 (1995), pp. 191-194.

(4) M.T. S.R. Gomes, M. I.S. Verissimo, J. A.B.P Oliveira, Detection of volatile amines using a quartz crystal with gold electrodes, Sens. Actuators B, Vol. 57 (1999), pp. 261-267.

(5) L. Spassov, V. Georgiev, L. Vergov, N. Vladimirova, Thermosensitive quartz resonators at cryogenic temperatures, Sens. Actuators A, Vol. 62 (1997), pp. 484487.

(6) T.G. Leblois, C.R. Tellier, Some investigations on doubly-rotated quartz resonant temperature sensors, Sens. Actuators A, Vol. 99 (2002), pp. 256-269.

(7) F.P. Delannoy, B. Sorli, A. Boyer, Quartz Crystal Microbalance (QCM) used as humidity sensor, Sens. Actuators A, Vol. 84 (2000), pp. 285-291.

(8) Y. Zhang, K. Yu, R. Xu, D. Jiang, L. Luo, and Z. Zhu, Quartz crystal microbalance coated with carbon nanotube films used as humidity sensor, Sens. Actuators A, Vol. 120 (2005), pp. 142-145.

(9) K. Kon, N. Tsukahara, M. Shimomura, DNA sensing with a quartz crystal device for determination of microorganisms, Sens. Actuators B, Vol. 123 (2007), pp. $647-650$.

(10) A. Ballato and R. Bechman, Effect of initial stress in vibrating quartz plates, Proc. IRE, Vol. 48 (1960), pp. 261-262.

(11) J. Ratajski, Force frequency coefficient of singly rotated vibrating quartz crystals, IBMJ. Dev. Res. (1968), pp. 92-99.

(12) E. Bens, M. Groschl, W. Burger, and M. Schmid, Sensors based on piezoelectric resonators, Sens. Actuators A, Vol. 48 (1995), pp. 1-21.

(13) B. Dumlet, R. Bourquin, and N. Shibanova, Frequency-output force sensor using a multimode doubly rotated quartz resonator, Sens. Actuators A, Vol. 48 (1995), pp. 109-116.

(14) S. Muraoka, Force sensor with quartz resonators by differential method, Trans. SICE, Vol. 33, No. 12 (1997), p. 1117-1123.

(15) L. D. Clayotn, E. P. EerNisse, Quartz Thickness-shear mode pressure sensor design for enhanced sensitivity, IEEE Trans. Ultrason., Ferroelect., Freq. Contr., Vol. 45, No. 5 (1998), pp. 1196-1203.

(16) Y.G. Dong, J.S. Wang, G.P. Feng, and X.H. Wang, Self-Temperature-Testing of the Quartz Resonant Force Sensor, IEEE Trans. Instrum. Meas, Vol. 48, NO. 6 (1999), pp. 1038-1040.

(17) E.P. EerNisse, Review of Thickness-Shear Mode Quartz Resonator Sensors for Temperature and Pressure, IEEE Sens. J., Vol. 1, NO. 1 (2001-1), pp. 79-87.

(18) Z. Wang, H. Zhu, Y. Dong, and G. Feng, A thickness-shear quartz force sensor with dual-mode temperature compensation, IEEE Sens. J., Vol. 3, No. 4 (2003-8), pp. 490-497.

(19) F. R. Blom, S. Bouwstra, J. H. J. Fluitman, M. Elwenspoek, Resonating Silicon Beam Force Sensor, Sens. Actuators, Vol. 17, (1989), pp. 513-519.

(20) S. Muraoka, H. Nishimura, Characteristics of a rectangular AT cut quartz resonator as a force sensor, Trans. SICE, Vol. 32, No. 4 (1997), pp. 604-606.

P. Kim, Microcontroller oscillator design guide, AN588 by Microchip Technology Inc., (1997) 